\title{
Janji Negara Donor Tsunami Aceh Dalam Perspektif Hukum Internasional
}

\author{
Sefriani
}

\begin{abstract}
Abstrak
Signature, exchange of instruments or ratification will be binding if the text provides that these actions are to have that effect. $A$ treaty which merely needs signatures from the parties, it will be legally binding to the parties by signing the treaty. However, for a treaty which needs ratification, signatures of the parties will not have a legal effect to the parties. The parties who have signed the treaty is only bound morally. Thus, the treaty will be legally binding to the parties, if the parties have ratified it.
\end{abstract}

\section{Pendahuluan}

Gelombang Tsunami 26 Desember 2004 yang lalu, bencana alam terbesar kurun waktu empat dasawarsa terakhir yang menimpa Aceh, Nias, dan Sumatera Utara juga beberapa negara seperti Srilanka, Malaysia, India, Thailand, dan Maladewa, tidak hanya membangkitkan solidaritas nasional tetapi juga internasional. Solidaritas itu ditandai dengan mengalirnya bantuan dari berbagai komponen masyarakat internasional.

Bentuk bantuan dari masyarakat internasional beraneka ragam bentuknya, yang secara garis besar terbagi menjadi lima yaitu barang, tenaga, peralatan, keahlian dan uang tunai'. Bantuan ada yang segera atau langsung dapat dinikmati korban bencana namun banyak pula yang masih berupa janji. Bantuan yang langsung dinikmati korban bencana adalah bantuan yang berbentuk barang, tenaga, peralatan dan keahlian². Dapat disaksikan bagaimana anggota-anggota militer negaranegara sahabat dengan keahlian dan teknologi yang mereka miliki memberikan bantuan langsung pada rakyat Aceh seperti penyediaan alat-alat berat dan transportasi udara, penyediaan air bersih, penyediaan tenaga medis dan obatobatan, membersihkan puing-puing dan mayatmayat yang berserakan, mengevakuasi korbankorban yang terisolir, dan mengangkut barangbarang kebutuhan pokok para korban. Bantuan seperti ini sebagaimana dikemukakan langsung dapat dinikmati korban bencana. Bantuan semacam ini jika dinilai dengan uang tentu bukan jumlah yang sedikit. ${ }^{3}$

'Gazalba Saleh, "Menagih Janji Negara Donor", dalam Harian Pikiran Rakyat, 1 Pebruari 2005

${ }^{2} \mathrm{lbid}$

${ }^{3} \mathrm{lbid}$ 
Di samping bantuan langsung berupa barang, tenaga, peralatan, keahlian, dan uang tunai ada juga bantuan-bantuan yang masih berupa janji. Segera, setelah bencana tsunami diketahui secara luas ke seluruh penjuru dunia, dengan emosional berbagai negara menyatakan akan memberikan bantuan. Dari hari ke hari jumlah bantuan yang dijanjikan semakin banyak. Pada waktu Konferensi khusus pemimpin ASEAN pasca tsunami di Jakarta 6 Januari 2005 bantuan darurat 977 juta dolar AS dan khusus untuk Aceh 3,5 miliar dolar AS. Dua minggu setelah konferensi, komitmen bantuan bertambah menjadi 9 miliar dolar AS dan bahkan mencapai 12 miliar. $^{4}$

Hari demi hari bahkan telah berganti bulan, ternyata kucuran dana yang dijanjikan negara-negara donor sangat lambat mengalir, padahal dana tersebut tentu sangat dibutuhkan bagi kelangsungan hidup korban yang masih selamat sebagaimana dikemukakan Kofi Annan yang mendesak negara-negara donor segera merealisasikan janjinya. ${ }^{5}$ Negara-negara korban tsunami khususnya Indonesia yang mengalami kerusakan terparah, sangat membutuhkan dana tersebut untuk membangun kembali wilayah yang rusak parah akibatbencana yang maha dahsyat itu. Apayang dialami Indonesia bukanlah hal yang pertama. Ketika Kota Bam (Iran) diguncang gempa bumi dahsyat dan menewaskan lebih dari 26 ribu jiwa Desember 2003 yang lalu para pemimpin dunia menjanjikan bantuan sebesar 1,1 miliar dolar AS. Namun realisasinya hanya 17,5 juta dolar AS. Begitu pula saat Mozambique dilanda banjir tahun 2000 yang lalu dari janji 400 juta dolar AS hanya setengahnya saja yang terealisasi. Kasus serupa ketika bencana topan menghancurkan Mitchi di Honduras dan Nikaragua pada tahun 1998, janji negara donor 8,7 miliar dolar AS, kurang dari sepertiga yang terealisasi. Berangkat dari pengalaman-pengalaman itulah tidak berlebihan kiranya apabila Sekretaris Jenderal PBB Kofi Annan jauh-jauh hari sudah memperingatkan supaya negaranegara korban bencana tidak berharap terlalu banyak dari janji-janji manis itu. Hal senada juga dikemukakan oleh Roberty Smith, juru bicara United Nations of the Resque Team, yang mengemukakan bahwa jangan kaget bilamana bencana besar biasanya menghasilkan banyak janji manis yang tidak selalu menjadi kenyataan. ${ }^{6}$

Berkaitan dengan paparan di atas menarik kiranya untuk mengkaji bagaimana sebenarnya janji negara donor tsunami Aceh dalam perspektif hukum internasional. Apakah janji tersebut mengikat secara hukum? Dapatkah Indonesia juga Negara-negara korban lainnya menuntut realisasi janji tersebut? Adakah upaya-upaya yang dapat. dilakukan supaya negara korban tidak hanya menerima janji kosong dan sebaliknya negara donor tidak mudah mengumbar janji kosong?

\section{Kesediaan Negara Donor Membantu Dana Pemulihan Aceh \\ Dibandingkan 10 negara lainnya korban tsunami Desember 2005, Indonesia merupakan negara yang mengalami kerusakan terparah. Disamping ratusan ribu korban jiwa yang tidak dapat tergantikan, kerugian material diperkirakan mencapai 40 triliun rupiah.}

\footnotetext{
${ }^{4 " N e g a r a ~ d o n o r ~ d i d e s a k ~ r e a l i s a s i k a n ~ b a n t u a n n y a ", ~ d a l a m ~ h a r i a n ~ P i k i r a n ~ R a k y a t, ~ 13 ~ J a n u a r i ~} 2005$ ${ }^{5}$ lbid

${ }^{6}$ Gazalba Saleh, loc.cit
} 
Diperlukan dana yang sangat besar tentunya

Beberapa negara yang tercatat telah untuk merehabilitasi dan merekonstruksi wilayah yang hancur akibat terjangan tsunami. untuk Aceh adalah sebagai berikut: ${ }^{7}$

Tabel 1 Negara Donor Untuk Tsunami Aceh

\begin{tabular}{|c|c|c|c|c|}
\hline Negara & $\begin{array}{c}\text { Jumlah } \\
\text { (Komitmen) }\end{array}$ & Penggunaan & Sifat & Status \\
\hline Amerika Serikat & UU\$ 489,15 juta & $\begin{array}{l}\text { Perumahan dan lingkungan bagi } \\
\text { masyarakat, jalan, jembatan dan sistem } \\
\text { pengairan juga erly waming system dan } \\
\text { perencanaan penanggulangan bencana }\end{array}$ & Hibah (grant) & $\cdot$ \\
\hline Australia & US $\$ 416,00$ juta & $\begin{array}{l}\text { Pembangunan infrastrukturRS Zainoel } \\
\text { Abidin, penyiapan tenaga kesehatan, } \\
\text { pelatihan guru, pembangunan pelayanan } \\
\text { pemda dan memperkuat kelembagaan } \\
\text { Bakomas }\end{array}$ & Hibah (grant) & $\begin{array}{l}\mathrm{T} \text { e I a } \mathrm{h} \\
\text { ditandatangani }\end{array}$ \\
\hline Austria & US $\$ 10$, Juta & Rekonstruksi & Pinjaman & - \\
\hline Cina & US $\$ 24,75$ Juta & $\begin{array}{l}\text { Perumahan pengungsi, earty:waming } \\
\text { system dan rehabilitasi jalan }\end{array}$ & Hibah (grant) & $\cdot$ \\
\hline Denmark & US $\$ 18,00$ Juta & Air bersih dan sanitasi & Hibah (grant) & - \\
\hline Jepang & US\$ 147,49 Juta & $\begin{array}{l}\text { Rehabilitasi jalan, pasar, sekolah, pesantren, } \\
\text { puskesmas, panti asuhan dan fasilitas } \\
\text { perikanan. }\end{array}$ & Hibah (grant) & $\begin{array}{l}\text { Penyampaian } \\
\text { Rincian kegiatan }\end{array}$ \\
\hline Jerman & US $\$ 7,86$ Juta & $\begin{array}{l}\text { Pendidikan, kesehatan, air bersih, \& } \\
\text { transportasi }\end{array}$ & Hibah (grant) & $\begin{array}{l}\text { Penandatanganan } \\
\mathrm{N} \text { a s k a h } \\
\text { Kerjasama }\end{array}$ \\
\hline Kanada & US $\$ 63,90$ Juta & UKM, gender dan tata pemerintahan & Hibah (grant) & - \\
\hline Kuwait & US $\$ 170,00$ Juta & Rehabilitas dana rekonstruksi & $\begin{array}{l}\text { - Hibah (grant): } \\
\text { US } \$ 100,0 \text { Juta } \\
\text { - P inja man : } \\
\text { US } \$ 70,00 \text { Juta }\end{array}$ & $\cdot$ \\
\hline Korea Selatan & US $\$ 13,70$ Juta & $\begin{array}{l}\text { Rehabilitas sekolah dan balai latihan kerja } \\
\text { serta rekonstruksi Rumah Sakit dan } \\
\text { pengadaan rumah sakit }\end{array}$ & Hibah (grant) & - \\
\hline Norwegia & US\$2,19 Juta & $\begin{array}{l}\text { Pemetaan wilayah pantai barat NAD dan } \\
\text { Sumut }\end{array}$ & Hibah (grant) & $\cdot$ \\
\hline
\end{tabular}

${ }^{7} \mathrm{RI}$, Rencana Induk rehabilitasi dan Rekonstruyksi Wilayah Aceh dan Nias, Sumatera Utara, Bukü Ẍl :Pendanaan, April 2005, hlm. 10-11, www.indonesia.sk/wni/press/aceh/buku-7-agama-sosbud.pdf 
Di samping negara secara bilateral, lembaga multilateral antara lain sebagai bantuan juga dijanjikan oleh beberapa berikut: ${ }^{8}$

Tabel 2 Bantuan Lembaga Multilateral

\begin{tabular}{|c|c|c|c|c|}
\hline Negara & $\begin{array}{c}\text { Jumlah } \\
\text { (Komitmen) }\end{array}$ & Penggunaan & Sifat & Status \\
\hline Bank Dunia (World Bank) & US\$301,00 Juta & Belum ditentukan & Pinjaman (loan) & $\begin{array}{l}\mathrm{S} \text { e d a } \mathrm{n} \mathrm{g} \\
\text { didiskusikan }\end{array}$ \\
\hline $\begin{array}{l}\text { Bank Pembangunan Asia } \\
\text { (Asian Development Bank) }\end{array}$ & US $\$ 401,30$ Juta & $\begin{array}{l}\text { Berbagai proyek } \\
\text { pertanian, perikanan, } \\
\text { UKM, dll }\end{array}$ & $\begin{array}{l}\text { Hibah (grant) US\$275,00 } \\
\text { JutaPinjaman (loan) US\$ } \\
\text { 126,30 Juta }\end{array}$ & $\begin{array}{l}\mathrm{N} \text { a } s \mathrm{k} \text { a } h \\
\text { pejanjilan hibah } \\
\mathrm{s} \text { e d a } \mathrm{n} \text { g } \\
\text { dineoosiasikan }\end{array}$ \\
\hline $\begin{array}{l}\text { PBB (United National) } \\
\text { Bank Pembangunan Islam } \\
\text { (Islamic Development Bank) }\end{array}$ & $\begin{array}{l}\text { US } \$ 371,00 \text { Juta } \\
\text { US } \$ 213,00 \text { Juta }\end{array}$ & $\begin{array}{l}\text { Belum ditentukan } \\
\text { Belum ditentukan }\end{array}$ & $\begin{array}{l}\text { Hibah (grant) } \\
\text { Hibah (grant) US } \$ 3,00 \\
\text { Juta Pinjaman (loan) US } \$ \\
210,00 \text { Juta }\end{array}$ & $\begin{array}{l}\text { MOU telah } \\
\text { ditandatangani }\end{array}$ \\
\hline
\end{tabular}

Berdasarkan data yang dipaparkan di atas dapat diketahui bahwa, ternyata dana yang dijanjikan negara atau lembaga donor ada yang berupa hibah (grant) dan ada pula yang berupa pinjaman (loan). Lebih lanjut, bantuan dari masyarakat internasional juga ada yang berbentuk moratorium atau penundaan pembayaran kewajiban pembayaran hutang. Paris Club pada sidang tanggal 9 Maret 2005 telah memutuskan untuk memberikan moratorium utang kepada negara yang terkena bencana ts!nnami. Indonesia mendapatkan moratorium sebesar Rp. 3,9 triliun. Pembayaran hutang yang jatuh tempo tahun ini ditangguhkan selama 5 tahun dengan masa tenggang satu tahun. Dengan adanya moratorium tersebut, Pemerintah Indonesia pada tahun anggaran 2005 dapat memiliki ruang gerak yang lebih lapang untuk penyediaan dana rehabilitasi dan rekonstruksi. Meskipun demikian moratorium tersebut adalah penundaan beban, oleh karena itu pemerintah harus mempertimbangkan beban anggaran pada saat penundaan tersebut jatuh tempo Pemerintah Indonesia telah menyatakan persetujuannya untuk menerima tawaran moratorium tersebut. Dengan diterimanya moratorium tersebut, maka pemerintah Indonesia akan kehilangan sebagian hibah dari beberapa negara donor sebagai ganti (trade off) atas fasilitas moratorium, diantaranya pemerintah Indonesia akan kehilangan hibah dari Amerika Serikat sebesar Rp 270,0 miliar. $^{9}$

Berkaitan dengan status janji negara donor dapat dicermati dari data yang telah dipaparkan sebelumnya ada yang statusnya sudah dalam bentuk perjanjian, draft, tetapi ada pula yang statusnya belum jelas karena hanya diucapkan secara lisan ataupun tertulis dalam bentuk nota diplomatik. Status janji atau komitmen negara donor ini sangat penting artinya bagi Indonesia, supaya tidak terulang kasus-kasus sebelumnya dimana negara korban bencana alam hanya disuguhi janjijanji kosong. Sebagaimana dikemukakan sebelumnya PBB melalui Sekretaris Jenderal-

9/bid, him.9

${ }^{8} /$ bid, hlm.12 
nya jauh-jauh hari sudah mengingatkan negara donor untuk segera mencairkan dana yang dijanjikannya, tidak memberikan janji kosong dan sebaliknya bagi negara korban bencana diharap tidak terlalu banyak berharap pada janji-janji itu.

\section{Perjanjian tertulis dan tidak tertulis dalam Konvensi Wina 1969 tentang perjanjian internasional}

Konvensi Wina 1969 tentang perjanjian internasional tidak membuat klasifikasi antara perjanjian tertulis dan perjanjian tidak tertulis. Demikian halnya tidak ditemukan definisi apa yang dimaksud dengan perjanjian tertulis dan perjanjian tidak tertulis.

Istilah perjanjian tidak tertulis (intemational agreement not in written form). Di dalam Konvensi Wina 1969 tentang perjanjian internasional ditemukan dalam Pasal 3, yang menetapkan sebagai berikut: ${ }^{10}$

"the fact that the present convention does not apply to international agreements concluded between states and other subjects of international law or between suchother subjects of international law, or to international agreements not in written form..."

Dari penegasan pasal tersebut dapat ditarik kesimpulan bahwa sesungguhnya ada perjanjian tertulis dan ada perjanjian tidak tertulis. Adapun Konvensi Wina 1969 tidak dapat diberlakukan untuk perjanjian yang tidak tertulis ((international agreement not in written form). Hal ini sebenarnya sudah ditegaskan dalam Pasal 2 konvensi tersebut yang menetapkan bahwa konvensi hanya diterapkan terhadap perjanjian internasional (treaties) antar negara dan hanya untuk treaties in written form... yang diatur oleh hukum internasional."

Pembatasan ruang lingkup yang diberikan Pasal 2 ini tidak dimaksudkan untuk mengatakan bahwa perjanjian yang tidak tertulis atau perjańjian yang subjeknya bukan negara kemudian tidak dapat dikatakan sebagai perjanjian internasional. Pasal 2 Konvensi hanya bermaksud membatasi ruang lingkup penerapan konvensi supaya Konvensi tidak terlalu luas yang akan berakibat pada sulitnya perumusan pasal demi pasal dalam konvenși tersebut.

- Istilah perjanjian internasional tertulis (written agreement) memang dapat dihadapkan atau merupakan lawan kata dari perjanjian intemasional lisan (oral agreement). Tetapi istilah perjanjian internasional tidak tertulis tidak dapat disamakan begitu saja dengan perjanjian lisan (oral agreement). Perjanjian internasional tidak tertulis lebih luas isi dan ruang lingkupnya bila dibandingkan dengan perjanjian internasional lisan. Perjanjian lisan hanyalah merupakan salah satu contoh saja dari perjanjian yang termasuk kategori perjanjian internasional tidak tertulis. Beberapa contoh lain dari perjanjan intemasional tidak tertulis antara lain nota diplomatik, deklarasideklarasi sepihak, pejjanjian-perjanjian tersimpul (implied agreement), perjanjian-perjanjian yang dilakukan secara lisan disertai catatancatatan tertulis dalam nota resmi maupun nota pribadi, juga deklarasi bersama beberapa negara yang walaupun mungkin berupa bentuk tertulis tetapi tidak mengikuti prosedur

"Lihat Pasal 3 Konvensi Wina 1969 tentang Perjanjian Internasional

"Martin Dixon MA, Textbook on International Law, fourt edition, (Blackstone Press Limited, 2000), hlm.57 
dan aturan sebagaimana ditentukan dalam Konvensi Wina 1969 tentang perjanjian internasional ${ }^{12}$. Brownlie ${ }^{13}$ dan Mac Nair ${ }^{14}$ menggunakan istilah informal agreement untuk menyebut jenis-jenis perjanjan seperti ini.

Mengingat bahwa secara tegas Pasal 3 Konvensi Wina 1969 telah menyatakan tidak diberlakukan terhadap perjanjian tidak tertulis, maka rejim hukum perjanjian tidak tertulis atau perjanjian informal ini tunduk pada hukum kebiasaan intemasional (intemational customary law). Hukum kebiasaan internasional tumbuh dan berkembang melalui praktik masyarakat internasional.

Di antara para penulis hukum internasional ada yang menggolongkan hukum kebiasaan ini sebagai hukum perjanjian tak tertulis, sebab tunduknya negara pada hukum kebiasaan internasional diartikan sebagai kesediaan dan kesepakatan negara itu untuk tunduk dan terikat pada hukum kebiasaan internaisonal. Jadi ada semacam persetujuan tersimpul (implied consent).

\section{Berlaku (Entry Into Force) Dan Mengikat- nya (Bound) Perjanjian Tertulis}

Kapan suatu perjanjian mengikat dan kapan suatu perjanjian berlaku sangatlah penting untuk dipahami. Pasal 24 (1) Konvensi Wina 1969 menetapkan bahwa berlakunya suatu perjanjian internasional tergantung pada:

a. ketentuan perjanjian internasional itu sendiri b. atau apa yang telah disetujui oleh negara peserta

Untuk mengetahui kapan suatu perjanjian berlaku pada umumnya dapat dilihat di bagian klausula formal (klausula final) yang biasanya terletak di pasal-pasal terakhir perjanjian atau setelah pasal-pasal substansial (dispositive provision) perjanjian internasional tersebut. Sebagai contoh misalnya:

a. perjanjian berlaku segera setelah penandatanganan

b. perjanjian berlaku 60 hari setelah penandatanganan

c. perjanjian berlaku setelah terkumpul 30 piagam ratifikasi

d. perjanjian berlaku 30 hari setelah terkumpul 60 piagam ratifikasi

Adapun mengikatnya pejanjian tergantung pada tahap-tahap pembentukan perjanjian itu. Untuk perjanjian yang tidak memerlukan ratifikasi maka penandatanganan akan menimbulkan akibat hukum yaitu terikatnya negara penandatangan pada perjanjian tersebut. Namun bila perjanjian mensyaratkan ratifikasi maka negara akan terikat secara hukum hanya setelah ia meratifikasi. Penandatanganan tidak menimbulkan konsekuensi hukum, penandatanganan hanya berarti bahwa negara tersebut menyetujui teks perjanjian. Negara yang sudah menandatangani hanya terikat secara moral.

Antara mulai berlaku dan saat mengikatnya suatu perjanjian bisa bersamaan bisa pula tidak. Perjanjian yang tidak mensyaratkan ratifikasi dan menetapkan bahwa perjanjian itu akan berlaku segera setelah penanda-

${ }^{12}$ Wayan Parthiana, Beberapa Masalah dalam Hukum Internasional dan Hukum Nasional Indonesia, (Binacipta, Bandung, 1987), hlm. 114

${ }^{13}$ lan Brownlie, Principles of Public Intemational Law, $2^{\text {nd }}$ edition; (The Clarendon Press, Oxford), hlm.714

${ }^{14}$ Lord Mac Nair, The Law of Treaties, (The Clarendon Press, Oxford, 1961), hlm.7 
tanganan maka saat berlaku dan saat mengikatnya terjadi bersamaan. Negara yang menandatangani otomatis terikat pada perjanjian, ketika . kemudian ia melanggar issi; perjanjian dapat segera dituntut karena perjanjian itu juga sudah-berlaku.

Namun demikian pada contoh lain misalkan saja pada kasus Konvensi Hukum Laut 1982. Konvensi ini. mensyaratkan akan berlaku setelah terkumpul 60 piagam ratifikasi. Indonesia sudah meratifikasi Konvensi pada tahun 1985 sehingga pada tahun itu İndonesia sudah terikat pada perjanjian tersebut. Namun demikian pada, tahun itu Konvensi belum berlaku karena belum terkumpul, 60 piagam ratifikasi. Konvensi resmi berlaku pada November. 1996 pada saat negara ke 60 mengumpulkan piagam ratifikasi. Andaikan tahun 1990 Indonesia melanggar isi konvensi meskipun. Indonesia sudah terikat tetapi karena perjanjian belum berlaku maka Indonesia tidak dapat dituntut ke pengadilan atas dasar. Konvensi tersebut. Dengan demikian dapat: disimpulkan untuk dapat menuntut suatu. negara atas pelanggaran suatu perjanjian internasional ada dua syarat yang diperlukan yaitu , perjanjian itu sudah berlaku dan negara itu sudah mengikatkan diri pada perjanjian tersebut.

Dalam kaitannya dengan janji negara donor Tsunami.Aceh, janji negara donor untuk memberikan bantuan yang sudah berstatus jelas atau sudah ditandatangani barulah jjanji yang berasal dari Australia serta Bank Pembangunan Islam. Adapun janji-janji yang lain ada yang draft perjanjiannya sedang dinegosiasikan tetapi sebagian besar yang lain statusnya tidak atau belum jelas. Sebagaima- na telah dipaparkan sebelumnya, perjanjian internasional tertulis, apapun namanya baru akan memberikan akibat hukum bilamana perjanjian tersebut sudah berlaku serta mengikat kedua belah pihak. Kapan perjanjian. tersebut berlaku dan mengikat, para pihak sendirilah, dalam hal ini Indonesia dengan Australia serta Indonesia dengan Bank Pembangunan Islam yang menentukan dalam perjanjian yang sudah mereka tandatangani tersebut. Untuk perjanjian dengan Bank Pembangunan Islam berdasarkan Pasal 10 UU Nomor 24 Tahun 2000 memerlukan persetujuan, $\mathrm{DPR}$, Hal -ini dikarenakan perjanjian tersebut merupakan perjanjian hutang, yaitu. USS $\$ 10$ juta hutang dan hanya US $\$$ juta yang merupakan hibah Adapun berkaitan dengan janji Australia perlu dikaji lagi apakah hibah termasuk dalam perjanjian yang harus diratifikasi menurut Uut Nomor 24 Tahuun 2000:

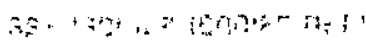

Pérjanjiân Ińteînásiónal Tak Tertulis Da: lam Praktek Hubungan Internasional $\because$ Kenyatan bahwa Konvens Wina 1969 tentang perjanjian internasional tidak berlaku bagi perjanjian-perjanjian internasional yang dibuat antara negara-negara dan subjeksubjek hukum internasional lainnya atau antara subjek-subjek hukum internasional lainnya, atau perjanjian intemasional tidak tertulis, namun konvensi menyatakan bahwa kenyataan ini tidak akan mempengaruhi kekuatan hukum, perjanjian-perjanjian terse but.

Senada dengan apa yang diatur dalam Konvensi Wina 1969 di atas, menurut Starke

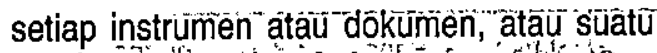

${ }^{15}$ Lihat Pasal 3 Konvensi Wina 1969 tentang perjanjian internaisonal sub paragraf $(a)$ 
pembicaraan lisan antar kepala negara yang menyangkut tindakan-tindakan oleh mereka dapat merupakan suatu traktat atau perjanjian internasiona, tanpa melihat kepada bentuk atau keadaan-keadaan pada saat pembentukannya. $^{16}$

Lebih lanjut pakar hukum internaisonal ini mengemukakan bahwa bentuk-bentuk traktat yang bagaimanapun tidak mempengaruhi sifat mengikatnya. Traktat tidak harus bentuk tertulis. Suatu pernyataan lisan yang bersifat janji yang dibuat oleh presiden, perdana menteri, menteri luar negeri suatu negara atas nama negara tersebut kepada menteri luar negeri atau pimpinan negara lain dalam masalah yang berada dalam kompetensinya dan otoritasnya dianggap mengikat sama seperti halnya sebuah traktat atau perjanjian internasioanl tertulis resmi. Hukum internasional sampai saat ini tidak mensyaratkan bentuk baku baki traktat-traktat tersebut, yang lebih penting adalah isi dan substansinya. ${ }^{17}$

Mengingat bahwa Konvensi Wina 1969 tentang perianjian internaisonal tidak berlaku untuk perjanjian internasional tidak tertulis maka sebagaimana dikemukakan sebelumnya perjanjian internasional tak tertulis ataupun yang juga sering disebut dengan istilah perjanjian informal tunduk pada rejim hukum kebiasaan internasional. Dalam paktik hubungan internasional dapat dikemukakan beberapa contoh kasus berkaitan dengan penggunaan perjanjian tak tertulis ini.

\section{a. Eastern Greenland Case .}

Pertama adalah kasus Eastern Greenland Case yang diputus oleh Mahkamah Internasional Permanen 1933 antara Denmark melawan Norwegia. Kasus ini mengenai status hukum Greenlandia Timur (Legal Status of Eastern Greenland). Duduk perkaranya secara singkat adalah sebagai berikut: Pemerintah Denmark telah lama menguasai wilayah atau jazirah di bagian utara Eropa yaitu yang disebut Tanah Hijau (Greenland). Dalam Konperensi Perdamaian Paris 1919, dicapai kesepakatan untuk membentuk sebuah komisi yang antara lain bertugas untuk menyelesaikan klaim-klaim beberapa negara terhadap Kepulauan Spitzbergen sebagai bagian wilayahnya. Pada lain pihak, Denmark mempunyai perhitungan lain. Denmark menginginkan supaya Norwegia tidak mengutak-atik kedaulatan Denmark atas Greenlandia Timur yang telah dikuasai dari dahulu olehnya. Sebagai imbalannya, Denmark tidak ikut mengklaim Kepulauan Spitzbergen dan menyatakan tidak berkeberatan atas tuntutan Norwegia atas Kepulauan Spitzbergen. Dengan kata lain, Denmark mendukung Norwegia atas Kepulauan Spitzbergen. Pernyataan dukungan ini disampaikan oleh seorang Menteri Denmark atas instruksi Menteri Luar Negerinya kepada Menteri Luar Negeri Norwegia pada waktu itu, Mr M Ihlen. Di samping menyatakan dukungan Denmark atas tuntutan Norwegia terhadap Kepulauan Spitzbergen, utusan itu juga mengemukakan bahwa Pemerintah Denmark sudah sejak lama memperoleh penga-

\footnotetext{
${ }^{16}$ Starke, JG, Pengantar Hukum Internasional, Buku ke-2, Edisi kesepuluh, diterjemahkan oleh Bambang Iriana Djajaatmadja, (Sinar Grafika, Jakarta, 1992), hlm.583

${ }^{.17} \mathrm{lbid}$, hlm. 586 .
} 
kuan dari pelbagai negara atas Greenlandia Timur itu. Pernyataan Atas tawaran Denmark ini pada tanggal 22 Juli 1919 M Ihlen dalam kapasitasnya selaku Menteri Luar Negeri Norwegia mengeluarkan statemen yang dicatat dalam sebuah nota yang antara lain menyatakan bahwa Pemerintah Norwegia tidak akan mempersulit masalah Greenlandia . Statemen Pemerintah Norwegia ini dicatat dengan baik oleh Denmark dan dianggap sebagai dukungan Norwegia atas kedaulatan Denmark di Greeniandia. Namun demikian beberapa waktu kemudian temyata Pemerintah Norwegia mengeluarkan pernyataaan yang sangat mengejutkan Denmark. Norwegia mengklaim memiliki kedaulatan atas bagian timur Greenlandia. Denmark memprotes dan tidak mengakui tindakan Norwegia itu, dan akhirnya sengketa ini disampaikan ke hadapan Mahkamah Internasional Permanen yang berkedudukan di Den Haag. ${ }^{18}$

Dalam persidangan Mahkamah Internasional Permanen dipermasalahkan apakah statemen atau deklarasi $M$ Innen selaku Menteri Luar Negeri Norwegia yang berjanji tidak akan mempersulit masalah Greenlandia menimbulkan kewajiban bagi Nonwegia untuk mengekang atau mengendalikan diri terhadap tindakan menguasai sebagian dari Greenlandia ataukah dipandang sebagai pengakuan Norwegia terhadap kedaulatan Denmark di Greenlandia. Di persidangan itu Mahkamah memeriksa nota-nota atau catatan-catatan kedua belah pihak Dalam pertimbangan putusannya, Mahkamah menyatakan bahwa pernyataan Denmark untuk tidak mempersulit posisi Norwegia mempertahankan kepulauan Splitzbergen dan sebaliknya statemen M Ihlen tidak akan mempersulit Denmark dalam soal Greenlandia merupakan dua hal yang saling berkaitan. Statemen-statemen yang dicatat dalam nota-nota itu dipandang melahirkan suatu ikatan perjanjian bilateral yang harus ditaati oleh kedua belah pihak ${ }^{19}$

\section{b. Kasus percobaan bom nuklir Perancis di Atol Aruroa}

Kasus ini bermula dari keinginan Perancis pada tahun 1973 untuk melakukan percobaan peledakan bom nuklir yang ditentang banyak negara termasuk mahkamah internasional yang membuat keputusan agar Perancis membatalkan niatnya meledakkan bom nuklir di Atol Aruroa, Kepulauan Pasifik. Perancis tidak menghiraukan protes masyarakat internasional dan tetap melaksanakan niatnya itu. Namun demikian Presiden Perancis kala itu, George Pompidou mengeluarkan pernyataan yang tidak hanya ditujukan pada negara-negara yang secara tegas memprotes rencana kegiatan Perancis tetapi ditujukan pada segenap masyarakat internasional. bahwa peledakan itu adalah yang pertama sekaligus yang terakhir bagi Perancis. Ucapan pimpinan Perancis ini dapat dipandang sebagai janji yang mengandung ikatan perjanjian dimana Perancis berkewajiban menepati pernyataan yang dibuat kepala negaranya dan sebaliknya melahirkan hak bagi negara-negara berkepentingan untuk menuntut supaya Perancis menaatinya. ${ }^{20}$

\footnotetext{
${ }^{18}$ Wayan Parthiana, op.cit, hlm.123

19lbid, him. 124

${ }^{20}$ Syahmin AK, Hukum Perjanjian Intemasional (Menurut Konvensi Wina 1969) (Armico Bandung), hlm.;6
} 
Mahkamah internasional menyatakan bahwa suatu deklarasi dapat dibuat dengan cara tindakan sepihak oleh suatu negara mengenai situasi hukum atau situasi faktual berdasarkan keadaan-keadaan (misalnya, dimuka umum dan erga omnes) yang berakibat menciptakan suatu kewajiban hukum atas negara tersebut. ${ }^{21}$

\section{c. Kasus Sabah}

Pada KTT ASEAN di Kuala Lumpur 1977 yang dihadiri kepala-kepala negara ASEAN (Indonesia, Malaysia, Philipina, Thailand, dan Singapura) Presiden Philipina kala itu, Ferdinand $E$ Marcos, dalam pidato sambutan pembukaannya menegaskan bahwa Philipina mencabut klaim atas Sabah yang sudah bergabung ke dalam Malaysia. Pidato Marcos ini mendapat sambutan hangat dan peserta KTT sebagai tanda solidaritas ASEAN. Bagi pihak Malaysia pidato ini akan dipandang sebagai pernyataan resmi Philipina melepaskan tuntutan atas Sabah sekaligus pengakuan negara tersebut atas penggabungan Sabah ke dalam Federasi Malaysia. Andaikata dikemudian hari terjadi perubahan sikap dari Philipina yang mungkin membàngkitkan kembali sengketa Sabah, Malaysia dapat menggunakan pidato Marcos sebagai salah satu argumentasi dan pegangan untuk menghadapi Philipina. Dalam hal ini, pidato Marcos dapat dianggap sebagai janji Philipina mengakui dan membenarkan penggabungan Sabah ke dalam Malaysia . Konsekuensinya adalah bahwa Philipina harus menaati apa yang telah diakui dan dibenarkannya itu. ${ }^{22}$

Dari kasus-kasus di atas nampak bahwa janji yang diucapkan kepala negara, kepala pemerintahan atau pimpinan suatu negara meskipun hanya diucapkan (lisan) atau dicatat dalam nota-nota resmi maupun pribadi dapat dianggap sebagai suatu perjanjian internasional. Perjanjian internasional ini menimbulkan kewajiban bagi pihak yang memberi janji untuk merealisasikan janjinya sebaliknya memberikan hak pada negara yang diberi janji untuk menuntut pelaksanaan janji tersebut. Perjanjian internasional tidak tertulis memiliki kekuatan mengikat yang. sama seperti halnya perjanjian tertulis.

Meskipun dalam praktik negara-negara perjanjian tak tertulis dapat dianggap sebagai suatu perjanjian internasional yang menimbulkan hak dan kewajiban bagi para pihaknya, namun perjanjian ini memiliki banyak kelemahan yang dapat lebih banyak mendatangkan kesulitan daripada manfaat.

\section{Kelemahan-kelemahan Perjanjian Tak Tertulis}

Konvensi Wina 1969 tentang Perjanjian internasional secara tegas menyatakan dirinya tidak berlaku untuk perjanjian tak tertulis. Praktik negara-negara juga menghindari penggunaan perjanjian tak tertulis. Hal ini semua dikarenakan perjanjian tak tertulis memiliki banyak kelemahan. Pertama, menurut Mac Nair bahwa perjanjian tak tertulis khususnya yang lisan tidak sejelas dan sama permanennya seperti halnya perjanjian tertulis. Dengan kata lain dapat dikatakan bahwa perjanjian tak tertulis kurang memberikan kepastian hukum. Hal ini justru bertentangan dengan Konvensi Wina 1969 yang bertujuan

\footnotetext{
${ }^{21}$ Starke, op.cit, him.632

${ }^{22}$ Lord MacNair, Op.Cit, hlm. 105-107
} 
memberikan kepastian hukum bagi pihakpihak yang hendak atau yang telah mengikatkan diri pada suatu perjanjian internasional sehingga perselisihan-perseli-sihan yang timbul sebagai akibat ketidak-jelasan isi maupun bentuk perjanjian dapat dicegah atau setidak-tidaknya dapat dikurangi. ${ }^{23}$ Janji lisan sulit dibuktikan bilamana tidak ada saksi atau saksi-saksi yang pada saat itu tidak mau memberikan kesaksian, memberikan kesaksian yang tidak benar ataupun mereka sudah meninggal semua.

Kedua, menurut Mac Nair perjanjian tak tertulis bersifat tidak demokratis. Dua orang apapun kedudukannya, sudah dapat mengikatkan negaranya dalam suatu ikatan persetujuan, yang berarti tindakan dua orang tersebut mengikat jutaan warganya tanpa campur tangan atau keturutsertaan dari badan yang berwenang dari negara tersebut. ${ }^{24}$

Meskipun mengakui kelemahankelemahan perjanjian tak tertulis namun Mac Nair menyatakan bahwa dalam praktik perjanjian tak tertulis sudah biasa muncul dan kadangkala tidak bisa dicegah seperti layaknya pergaulan antar manusia. Seperti halnya dalam pergaulan hidup nasional, dalam pergaulan internasionalpun tidak semua hal bisa diatur dalam bentuk tertulis atau formal. Meskipun memiliki banyak kelemahan namun menurut Mac Nair kekuatan mengikat perjanjian tak tertulis sama dengan perjanjian internasional tertulis. ${ }^{25}$
Janji Negara Donatur Tsunami Aceh dalam Perspektif Hukum Internasional .:

Berdasarkan paparan di atas, jánji negara-negara donor maupun organisasiorganisasi internasional untuk memberikan bantuan (hibah) pada Indonesià sebagai saiah atau negara korban tsunami, lebih banyak yang berbentuk tidak tertulis (informal) atau statusnya belum jelas menurut istilah pemerintah Indonesia dibandingkan dengan yang berbentuk tertulis. Untuk perjanjian yang tertulis tidak akan mengalami banyak masalah karena pada umumnya perjanjian bilateral akan lebih mudah diberlakukan daripada perjanjian multilateral. Melalui perjanjian tertulis kepastian hukum akan lebih diperoleh, hak dan kewajiban masing-masing pihak, saat realisasi hibah termasuk cara penyelesaian sengketa yang muncul dari perjanjian tersebut.

Yang memerlukan lebih banyak perhatian pada hakikatnya adalah perjanjian-perjanjian yang tidak tertulis atau informal atau yang belum jelas statusnya. Fakta menunjukkan dalam kasus-kasus bencana sebelumnya banyak janji yang hanya merupakan janji kosong namun negara yang mendapat janji hanya berdiam diri. Agar kasus serupa tidak menimpa Indonesia dan negara-negara korban tsunami lainnya maka kelompok negaranegara ini harus melakukan terobosan baru dan mengambil langkah taktis menggalang kekuatan agar pemimpin-pemimpin negara donor tersebut tidak selalu membohongi publik internasional, tetapi harus memenuhi janjinya.

${ }^{23}$ Wayan Parthiana, Op.Cit, hIm. 121

${ }^{24}$ Lord MacNair, Op.Cit, hlm. 108.

${ }^{25} \mathrm{bid}$ 
Terobosan dapat dilakukan dengan mengajukan tuntutan baik melalui jalur diplomasi maupun jalur hukum. Jalur diplomasi dapat secara bilateral, maupun memanfaatkan jasa pihak ketiga seperti organisasi rẹgional maupun internasional. PBB misalnya seharusnya bisa melakukan pendekatanpendekatan sampai tekanan untuk memaksa negara-negara donor merealisasikan janjinya. Tuntutan ini tidak dimaksudkan untuk memperkeruh suasana dalam tataran hukum internasional, tetapi dimaksudkan sebagai pembelajaran kepada pemimpin-pemimpin negara agar tidak mudah mengeluarkan janji atau pernyataan yang menimbulkan konsekuensi hukum.

Perjanjian yang tidak tertulis atau informal, termasuk di dalamnya perjanjian lisan mempunyai kekuatan mengikat yang sama dalam hukum internasional. Hukum internasional tidak mengatur bentuk baku suatu perjanjian internasional. Semua perjanjian itu melahirkan kewajiban bagi negara yang memberikan janji untuk menepatinya dan memberikan hak pada negara yang dijanjikan untuk menuntut realisasi hak tersebut.

\section{Simpulan}

Janji negara donor untuk memberikan bantuan (hibah) pada negara korban tsunami khususnya Indonesia baik yang berbentuk tertulis maupun tidak tertulis merupakan perjanjian internasional yang mengikat dalam perspektif hukum internasional. Janji negara donor sekalipun mungkin hanya dalam bentuk lisan menimbulkan kewajiban bagi negara yang bersangkutan untuk merealisasikan apa yang sudah mereka janjikan. Negara korban tsunami berhak menuntut realisasi janji tersebut. Tuntutan dapat dilakukan melalui jalur diplomasi maupun jalur hukum. Segenap masyarakat internasional termasuk di dalamnya PBB dan organisasi-organisasi regional seharusnya membantu negara korban tsunami mendapatkan haknya. Hal ini untuk pembelajaran pada pimpinan masyarakat internasional supaya tidak terus menerus melakukan kebohongan publik, dan supaya mereka berhatihati terhadap janji yang mereka ucapkan, karena meskipun bentuknya tidak tertulis tetapi memiliki kekuatan mengikat yang sama dengan perjanjian intemasional yang tertulis.

\section{Daftar Pustaka}

Gazalba Saleh, "Menagih Janji Negara Donor", dalam Harian Pikiran Rakyat, 1 Pebruari 2005

Ian Brownlie, Principles of Public International Law, $2^{\text {nd }}$ edition, The Clarendon Press, Oxford

I Wayan Parthiana, Beberapa Masalah dalam Hukum Internasional dan Hukum Nasional Indonesia, Binacipta, Bandung, 1987

"Negara donor didesak realisasikan bantuannya", dalam harian Pikiran Rakyat, 13 Januari 2005

Lord Mac Nair, The Law of Treaties, The Clarendon Press, Oxford, 1961

Martin Dixon MA, Textbook on International Law, fourt edition, Blackstone Press Limited,2000

Rl, Rencana Induk rehabilitasi dan Rekonstruyksi Wilayah Aceh dan Nias, Sumatera Utara, Buku XI :Pendanaan, April 2005, hlm. 10-11 www.indonesia. sk/wni/press/aceh/buku-7-agamasosbud.pdf 
Starke, JG, Pengantar Hukum Intemasional, Buku ke-2, Edisi kesepuluh, diterjemahkan oleh Bambang Iriana Djajaatmadja, Sinar Grafika, Jakarta, 1992

Syahmin AK, Hukum Perjanjian Internasional (Menurut Konvensi Wina 1969) Armico Bandung
I Wayan Parthiana, Beberapa Masalah dalam Hukum Internasional dan Hukum Nasional Indonesia, Binacipta, Bandung, 1987, hlm. 114

Konvensi Wina 1969 tentang Perjanjian Internasional 